\title{
Antinociceptive and anti-inflammatory effects of Caesalpinia pyramidalis in rodents
}

\author{
Cliomar A. Santos, ${ }^{1}$ Ailane M. P. R. Passos, ${ }^{1}$ Fernando C. \\ Andrade, ${ }^{2}$ Enilton A. Camargo, ${ }^{1}$ Charles $S$. Estevam, ${ }^{3}$ Márcio \\ R. V. Santos, ${ }^{2}$ Sara M. Thomazzi ${ }^{*}, 1$
}

${ }^{1}$ Laboratório de Farmacologia da Inflamação, Departamento de Fisiologia, Universidade Federal de Sergipe, Brazil;

${ }^{2}$ Laboratório de Farmacologia Cardiovascular, Departamento de Fisiologia, Universidade Federal de Sergipe, Brazil;

${ }^{3}$ Laboratório de Bioquímica, Departamento de Fisiologia, Universidade Federal de Sergipe, Brazil.

\begin{abstract}
Caesalpinia pyramidalis Tul., Fabaceae, is a plant with an antiinflammatory activity that is used in folk medicine. To evaluate the mechanism of action of this plant, studies were performed on its antinociceptive and antiinflammatory properties using an ethanol extract (EE) made from the inner bark. Oral treatment of mice with the EE $(100,200$, and $400 \mathrm{mg} / \mathrm{kg})$ decreased their acetic acid-induced abdominal writhes $(p<0.001)$ and their formalin-induced paw licking in both the first and second phases $(p<0.001)$. This treatment increased the reaction time of mice on the hot-plate test $(400 \mathrm{mg} / \mathrm{kg}, p<0.05$ ); however, it did not alter their performance on the Rotarod performance test. The carrageenan-induced paw edema in the rats and the leukocyte migration into the peritoneal cavity of the mice were also reduced by the EE given at a dose of $400 \mathrm{mg} / \mathrm{kg}(p<0.05)$. In addition, the EE $(100-400 \mathrm{mg} / \mathrm{kg}, v . o$.) did not alter the arterial pressure of non-anesthetized rats. In conclusion, the EE of $C$. pyramidalis shows antinociceptive and anti-inflammatory activities in rodents, supporting the usage of this plant to treat various inflammatory diseases for which it has traditionally been used.
\end{abstract}

Revista Brasileira de Farmacognosia Brazilian Journal of Pharmacognosy 21(6): 1077-1083, Nov./Dec. 2011

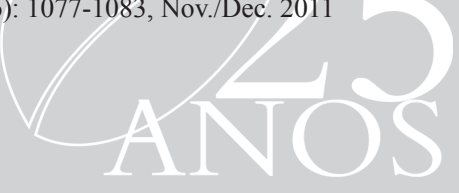

Article

Received 4 Aug 2010

Accepted 16 Feb 2011

Available online 30 Sep 2011

Keywords:

Anti-inflammatory antinociceptive

Caesalpinia pyramidalis Fabaceae

ISSN 0102-695X http://dx.doi.org/10.1590/S0102 $695 \times 2011005000179$

\section{Introduction}

Inflammation is one of the most important processes involved in the defense of an organism, however, it often progresses to painful and sometimes chronic diseases needing pharmacological treatment. Unfortunately, the therapies currently available to treat inflammation and pain are associated with unwanted side effects and low efficacy. There has been a resurgence of interest in herbal medicines in Western countries (Phillipson \& Anderson, 1989) as alternative sources of drugs for often intractable diseases.

Previous studies of species of the genus Caesalpinia, Fabaceae, report remarkable biological activities, such as antimicrobial (Saeed \& Sabir, 2001), antidiabetic (Sharma et al., 1997) (C. bonducella), antimalarial (Deharo et al., 2001; Kuria et al., 2001) (C. volkensii, C. pluviosa), and anti-inflammatory (Hikino et al., 1977; Carvalho et al., 1996) (C. sappan, C. ferrea) activities.

Caesalpinia pyramidalis Tul. is an endemic tree of northeastern region of Brazil and is one of the predominant species in the "caatinga" vegetation. The plant C. pyramidalis, known as "catingueira," is a plant species used in folk medicine to treat cough, bronchitis, respiratory infection, influenza, asthma, gastritis, colic, fever, heartburn, flatulence, diarrhea, collision, injury, diabetes, and stomach ache and is used as an aphrodisiac and expectorant (Albuquerque et al., 2007).

In this study, we evaluate the antinociceptive and anti-inflammatory effects of the ethanol extract (EE) made from C. pyramidalis inner bark.

\section{Materials and Methods}

Plant material and extraction of Caesalpinia pyramidalis inner bark

The inner bark of Caesalpinia pyramidalis Tul., Fabaceae, was collected in the municipality of Canindé de São Francisco-SE, Brazil, in September 2008 (0966'00"S, 3778'94"W). The plant was authenticated by Professor Ana Paula Prata, Department of Biology, Federal University of Sergipe, and a voucher specimen was deposited in the Federal University of Sergipe 
Herbarium (number ASE 13,164). The inner bark was dried at $40{ }^{\circ} \mathrm{C}$ in a forced air oven for two days and subsequently powdered $(2.840 \mathrm{~g})$ and extracted by maceration at room temperature with $90 \%$ ethanol for five days. The extract was filtered in vacuum, and the solvent was removed using a rotary evaporator $\left(45^{\circ} \mathrm{C}\right)$. The percentage of yield of the EE was 2.6\% (73.8 g).

\section{Phytochemical screening}

The methods of Matos (1997) were used to screen the EE of $C$. pyramidalis inner bark used in this study for its chemical constituents.

\section{Animals}

Young adults Wistar rats (120-180 g) and Swiss mice (20-30 g) of both sexes were obtained from the Central Biotery of the Federal University of Sergipe (São Cristóvão, Brazil). Animals were maintained at controlled room temperature $\left(21 \pm 2{ }^{\circ} \mathrm{C}\right)$ with free access to food (Purina $\left.{ }^{\circledR}\right)$ and water, under a $12 \mathrm{~h}$ light/dark cycle. All the experimental procedures were carried out during the light period of the day (8:00 a.m. to 5:00 p.m.) and complied with the guidelines on animal care of the Federal University of Sergipe Ethics Committee for Animal Use in Research (CEPA/UFS 05/09).

\section{Acetic acid-induced abdominal writhes}

Abdominal writhes were induced by intraperitoneal (i.p.) injection of acetic acid $(0.6 \%, 0.1$ $\mathrm{mL} / 10 \mathrm{~g}$ ) in mice (Koster et al., 1959). Animals were pre-treated orally (p.o.) with C. pyramidalis EE (100$400 \mathrm{mg} / \mathrm{kg})$, vehicle $(0.2 \%$ Tween $80,0.1 \mathrm{~mL} / 10 \mathrm{~g})$, or acetylsalicylic acid (ASA, $300 \mathrm{mg} / \mathrm{kg}$ ) $60 \mathrm{~min}$ before initiating the algesic stimulation ( $n=6 /$ group). The abdominal writhes were observed for a period of $20 \mathrm{~min}$ and began $5 \mathrm{~min}$ after the injection of the nociceptive agent.

\section{Formalin test}

The formalin test was conducted according to the method of Hunskaar \& Hole (1987). Mice were pretreated with the $C$. pyramidalis EE (100-400 mg/kg, p.o. $60 \mathrm{~min}$ before the start of the experiment), vehicle $(0.2 \%$ Tween 80, p.o., $60 \mathrm{~min}$ before the start of the experiment), morphine $(10 \mathrm{mg} / \mathrm{kg}$, i.p., $30 \mathrm{~min}$ before the start of the experiment), or ASA (300 mg/kg, p.o., $60 \mathrm{~min}$ before the start of the experiment). An intraplantar injection of $2 \%$ formalin solution $(20 \mu \mathrm{L})$ was given to the right hindpaw of the animal ( $n=6 /$ group). The time that the animal spent licking or biting its paw was measured during the firstphase (0-5 $\mathrm{min})$ and the second-phase (15-30 $\mathrm{min}$ ) of the test.

\section{Hot-plate test}

Mice were pre-treated with $C$. pyramidalis EE (100-400 mg/kg, p.o.), vehicle (0.2\% Tween 80 , p.o.), or morphine $(3 \mathrm{mg} / \mathrm{kg}$, i.p.), and after $30 \mathrm{~min}$, they were placed on a metallic plate warmed to $55.0 \pm 0.5^{\circ} \mathrm{C}(\mathrm{n}=6 /$ group). In another set of experiments, naloxone $(5 \mathrm{mg} /$ $\mathrm{kg}$, i.p.) was injected $30 \mathrm{~min}$ prior of the EE $(400 \mathrm{mg} /$ $\mathrm{kg})$ or morphine $(3 \mathrm{mg} / \mathrm{kg})$ treatment $(\mathrm{n}=6 /$ group $)$. The time that elapsed between the start of the experiment and the appearance of reactions (latency, in seconds) to the thermal stimulus, such as lifting or licking the paws, was recorded as an index of nociception (Woolfe \& Macdonald, 1944). Measurements were performed 0, 30, 60,90 , and $120 \mathrm{~min}$ after the first thermal stimulus. To avoid damage to the animals, the maximal time standing on the plate was limited to $30 \mathrm{~s}$.

\section{Motor function assay: rotarod}

To evaluate the possible non-specific musclerelaxant or sedative effects of EE, mice were submitted to the Rotarod Performance Assay (Duham \& Miya, 1957). The rotarod apparatus (AVS, Brazil) consisted of a bar with a diameter of $3 \mathrm{~cm}$, subdivided into five compartments. Animals were treated with EE (100-400 mg/kg, v.o.), vehicle $(0.2 \%$ Tween 80 , p.o. $)$, or diazepam $(1.5 \mathrm{mg} / \mathrm{kg}$, i.p.), and after $60 \mathrm{~min}$, the animals were placed on the rotating rod ( $7 \mathrm{rpm}, \mathrm{n}=6 /$ group). The latency to falling was measured for up to $180 \mathrm{~s}$. The results are expressed as the average time (s) that the animals remained on the rotarod.

Measurement of edema and myeloperoxidase (MPO) activity in rat paws

The anti-inflammatory activity of the EE was studied using the paw edema induced by carrageenan $(1 \%, 0.1 \mathrm{~mL})$, which was administered into the subplantar region of the right hindpaw of the rat (Winter et al., 1962). C. pyramidalis EE (100-400 mg/kg, p.o.), dexamethasone ( $2 \mathrm{mg} / \mathrm{kg}$, s.c.), or vehicle $(0.2 \%$ Tween 80, p.o.) were administrated $1 \mathrm{~h}$ before the edematogenic agent was injected ( $n=6 /$ group). The paw edema was measured plethysmographically (model 7150, Ugo Basile, Varese, Italy) at $1,2,3$, and $4 \mathrm{~h}$ after the carrageenan was administered. The data obtained were expressed in $\mathrm{mL}$. The percentage inhibition was calculated based on the area under the time-course curves $\left(\mathrm{AUC}_{0-4 \mathrm{~h}}\right)$.

Myeloperoxidase activity was measured in paw tissue samples obtained from animals after the end $(4 \mathrm{~h})$ of edema measurement. These samples were homogenized in $50 \mathrm{mM}$ phosphate buffer ( $\mathrm{pH}$ 6.0) containing $0.5 \%$ hexadecyl-trimethylammonium bromide. These 
homogenates were incubated for $2 \mathrm{~h}$ at $60^{\circ} \mathrm{C}$ to inactivate endogenous catalases. The supernatants were mixed to a solution of o-dianisidine dihydrochloride $(0.167 \mathrm{mg} / \mathrm{mL}$, in $50 \mathrm{mM}$ phosphate buffer) containing $0.005 \%$ of $\mathrm{H}_{2} \mathrm{O}_{2}$. The changes of absorbance at $460 \mathrm{~nm}$ were measured with a microplate reader (Labsystem Multiskan, Helsinki, Finland). The results were expressed as units of MPO (UMPO)/mg tissue, where one UMPO is defined as the amount of enzyme that degrades $1 \mu \mathrm{mol}$ of $\mathrm{H}_{2} \mathrm{O}_{2} / \mathrm{min}$ (Bradley et al., 1982).

\section{Leukocyte migration into the peritoneal cavity of mice}

The leukocyte migration was induced by injection of carrageenan $(1 \%, 250 \mu \mathrm{L}, i . p$.) into the peritoneal cavity of mice ( $n=6 /$ group) $1 \mathrm{~h}$ after the administration of the EE (100-400 mg/kg, p.o.), vehicle $(0.2 \%$ Tween 80, p.o. $)$, or dexamethasone $(2 \mathrm{mg} / \mathrm{kg}$, s.c.) as previously described by Mendes et al. (2010). The mice were euthanized $4 \mathrm{~h}$ after the carrageenan injection, and $3.0 \mathrm{~mL}$ of saline containing EDTA (1.0 $\mathrm{mM})$ was injected into the peritoneal cavity. The peritoneal lavages were collected and centrifuged at $1000 \times g$, and the cell pellets were resuspended in 1 $\mathrm{mL}$ of saline. The total number of cells was counted in a Neubauer chamber, and cytospin preparations were stained with May-Grunwald-Giemsa for the differential leukocyte counts. The results were expressed as the number of leukocytes/mL.

\section{Measurement of blood pressure in non-anesthetized rats}

To measure the mean arterial pressure (MAP), the rats were anesthetized with sodium thiopental (50 $\mathrm{mg} / \mathrm{kg}$, i.p.). A polyethylene catheter was inserted into the abdominal aorta via the left femoral artery for pressure recordings. The catheter was filled with heparinized saline and placed under skin, exiting between the scapulae. Twenty-four hours after the surgery, the rats were placed in large individual cages, and the experiments were performed in non-anesthetized rats. The arterial catheter was connected to a precalibrated pressure transducer (Edwards Lifescience, Irvine, CA, USA), and pressure outputs were recorded in an amplifier-recorder (BioData, Model BD-01, PB, Brazil) connected to a personal computer equipped with an analog-to-digital converter board (DI148U, DATAQ Instruments, OH, EUA) (Menezes et al., 2007). After the hemodynamics parameters had stabilized, the MAP was recorded before (baseline values) and 1, 2, 3, and $4 \mathrm{~h}$ after oral administration of C. pyramidalis EE (100, 200, and $400 \mathrm{mg} / \mathrm{kg}$, p.o.).

\section{Statistical analysis}

The results are presented as the means \pm SEM of $\mathrm{n}$ animals per group. Statistical evaluation of the data was performed using one-way analysis of variance (ANOVA) followed by Tukey's test. $p$ values lower than 0.05 were considered significant.

\section{Results}

\section{Phytochemical screening}

Phytochemical screening showed that the EE of C. pyramidalis inner bark contains flavonoids, phenols, saponins, steroids, tannins, and triterpenes.

\section{Acetic acid-induced writhing in mice}

The writhes evoked by injection of acetic acid in the abdominal cavity were markedly reduced by the pre-treatment with $C$. pyramidalis EE at 100, 200, and $400 \mathrm{mg} / \mathrm{kg}(p<0.001$, Table 1). ASA (300 mg/kg) also significant inhibited $(p<0.001)$ the writhes induced by acetic acid (Table 1).

Table 1. The antinociceptive effect of Caesalpinia pyramidalis EE on acetic acid-induced writhing.

\begin{tabular}{lccc}
\hline Treatment & Dose $(\mathrm{mg} / \mathrm{kg})$ & Number of writhes & Inhibition $(\%)$ \\
\hline Vehicle & -- & $31.2 \pm 0.9$ & -- \\
EE & 100 & $24.7 \pm 0.7^{\mathrm{a}}$ & 20.9 \\
& 200 & $18.2 \pm 0.3^{\mathrm{a}}$ & 41.7 \\
& 400 & $9.5 \pm 0.7^{\mathrm{a}}$ & 69.5 \\
ASA & 300 & $7.5 \pm 0.5^{\mathrm{a}}$ & 75.9 \\
\hline $\mathrm{a}_{p}<0.001$ & &
\end{tabular}

${ }^{\mathrm{a}} p<0.001 v s$. vehicle ( $\mathrm{n}=6 /$ group $)$.

\section{Formalin reaction time in mice}

The intraplantar injection of the formalin solution produced nociceptive behavior in both the first and second phases (105 \pm 3 and $122 \pm 6$ s, respectively, Figure 1). C. pyramidalis EE produced marked inhibition of formalin-induced neurogenic $(45.5,31.9$, and $42.0 \%$ at 100,200 , and $400 \mathrm{mg} / \mathrm{kg}$, respectively, $p<0.001$ ) and inflammatory $(92.8,81.0$, and $93.0 \%$ at 100,200 , and $400 \mathrm{mg} / \mathrm{kg}$, respectively, $p<0.001$ ) phases (Figure 1). Similarly, morphine $(10 \mathrm{mg} / \mathrm{kg})$ caused significant inhibition of $75.9 \%$ and $96.3 \%$ of formalin-induced nociceptive behavior in the first and second phases, respectively $(p<0.001$, Figure 1$)$. ASA (300 mg/kg) caused inhibition of $90.6 \%$ in the second phase of formalin-induced nociception $(p<0.001$, Figure 1$)$.

\section{Hot-plate reaction time in mice}

The EE of C. pyramidalis (400 $\mathrm{mg} / \mathrm{kg}$ ) caused a significant increase in the pain latency in the hot-plate 
test $\left(55^{\circ} \mathrm{C}\right)$ at all time points analyzed $(p<0.05$, Table 2$)$. Similarly, morphine $(3 \mathrm{mg} / \mathrm{kg})$ caused a significant and marked increase in the reaction time of mice $(p<0.05$, Table 2). Naloxone ( $5 \mathrm{mg} / \mathrm{kg}$ ) significantly prevented the antinociceptive effect caused by both $C$. pyramidalis EE $(400 \mathrm{mg} / \mathrm{kg})$ and morphine $(3 \mathrm{mg} / \mathrm{kg})$ at all time points observed $(p<0.05$, Table 2$)$.

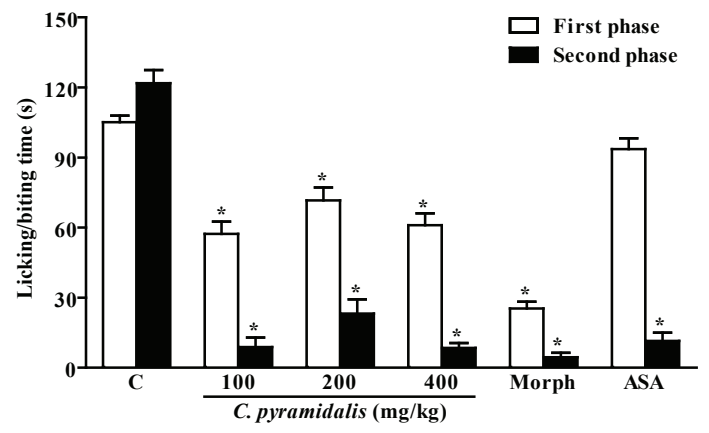

Figure 1. The effect of Caesalpinia pyramidalis EE on formalininduced nociception. Mice were pre-treated with vehicle (C), morphine (Morph, $10 \mathrm{mg} / \mathrm{kg}$ ), acetylsalicylic acid (ASA, 300 $\mathrm{mg} / \mathrm{kg})$, or EE $(100-400 \mathrm{mg} / \mathrm{kg})$ before a formalin injection. ${ }^{*} p<0.001 v s$. the respective control group ( $\mathrm{n}=6$ /group).

\section{Motor performance}

In the rotarod test, EE-treated mice did not show any significant motor performance alterations with the 100,200 , and $400 \mathrm{mg} / \mathrm{kg}$ dose $(180 \pm 0,180 \pm 0$, and $180 \pm 0 \mathrm{~s}$, respectively) compared to control mice (180 \pm 0 $\mathrm{s})$. As expected, the injection of the diazepam $(1.5 \mathrm{mg} / \mathrm{kg})$ reduced the time the mice were on the rotarod after the treatment $(31 \pm 3 \mathrm{~s}, p<0.001)$.

Carrageenan-induced edema and MPO activity in rat paws

As observed in Figure 2, the single oral treatment of $C$. pyramidalis $\mathrm{EE}$ at the $400 \mathrm{mg} / \mathrm{kg}$ dose was capable of reducing $(p<0.05)$ the edema induced by carrageenan at 2, 3 and $4 \mathrm{~h}$ after the injection of the phlogistic agent. Likewise, dexamethasone $(2 \mathrm{mg} / \mathrm{kg})$ inhibited $(p<0.01)$ the edematogenic response evoked by carrageenan in rats at 2, 3 and $4 \mathrm{~h}$ (Figure 2).

Based on $\mathrm{AUC}_{0-4 \mathrm{~h}}$ values, the $\mathrm{EE}$ at the $400 \mathrm{mg} /$ $\mathrm{kg}$ dose caused a $41.2 \%(p<0.05)$ inhibition of the edema response compared to carrageenan-treated group (4.6 \pm 0.7 $\mathrm{mLx}$ hour$)$. Dexamethasone $(2 \mathrm{mg} / \mathrm{kg})$ caused an inhibition of $54.4 \%(p<0.001)$.

C. pyramidalis EE $(400 \mathrm{mg} / \mathrm{kg})$ also produced a marked inhibition $(p<0.05)$ of carrageenan-induced MPO activity in the paws of rats compared to vehicletreated controls $(4.5 \pm 0.5$ and $7.1 \pm 0.9 \mathrm{UMPO} / \mathrm{mg}$ tissue, respectively). Similarly, dexamethasone (2 $\mathrm{mg} / \mathrm{kg})$ caused significant inhibition of carrageenan-induced
MPO activity (2.6 $\pm 0.3 \mathrm{UMPO} / \mathrm{mg}$ tissue, $p<0.001)$.

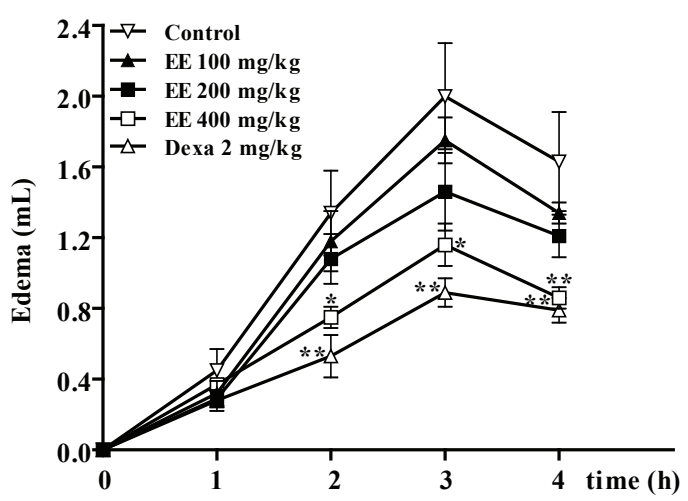

Figure 2. The effect of Caesalpinia pyramidalis EE on rat paw edema. Animals were pre-treated with vehicle (control), dexamethasone (Dexa, $2 \mathrm{mg} / \mathrm{kg}$ ), or EE (100-400 mg/kg) before a carrageenan injection. ${ }^{*} p<0.05$ and $* * p<0.01$ vs. the control group ( $\mathrm{n}=6 /$ group).

\section{Carrageenan-induced peritonitis in mice}

The carrageenan injection in control animals induced leukocyte migration into the peritoneal cavity after $4 \mathrm{~h}\left(7.22 \pm 0.99 \times 10^{6}\right.$ leukocytes $\left./ \mathrm{mL}\right)$. C. pyramidalis EE $(400 \mathrm{mg} / \mathrm{kg})$ significantly inhibited this response $\left(2.63 \pm 0.23 \times 10^{6}\right.$ leukocytes $\left./ \mathrm{mL}, p<0.01\right)$, but 200 or $100 \mathrm{mg} / \mathrm{kg}$ EE did not $\left(4.87 \pm 0.69 \times 10^{6}\right.$ and $7.09 \pm 1.03$ x $10^{6}$ leukocytes $/ \mathrm{mL}$, respectively). The dexamethasone injection also $(2 \mathrm{mg} / \mathrm{kg})$ inhibited $\left(0.68 \pm 0.40 \times 10^{6}\right.$ leukocytes $/ \mathrm{mL}, \quad p<0.001)$ the carrageenan-induced leukocyte migration.

The PMN migration evoked by carrageenan was reduced by 200 and $400 \mathrm{mg} / \mathrm{kg} \mathrm{EE}$ by $42.6 \%$ and $80.2 \%$ $(p<0.001)$, respectively (Figure 3$)$. Dexamethasone (2 $\mathrm{mg} / \mathrm{kg})$ exhibited significant inhibition $(95.7 \%, p<0.001)$ of the PMN migration in the control group (Figure 3 ).

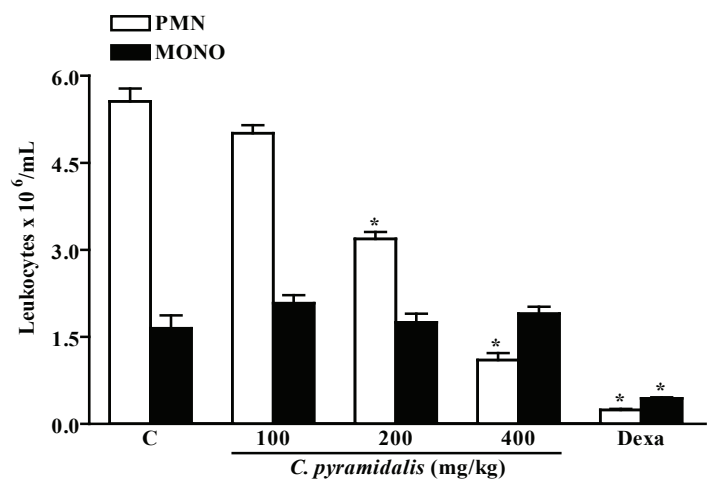

Figure 3. The effect of Caesalpinia pyramidalis EE on leukocyte migration. Mice were pre-treated with vehicle (C), dexamethasone (Dexa, $2 \mathrm{mg} / \mathrm{kg}$ ), or EE (100-400 mg/kg) before carrageenan-induced peritonitis. ${ }^{*} p<0.001$ vs. the respective control group ( $n=6 /$ group). 
Table 2. The antinociceptive effect of Caesalpinia pyramidalis EE using the hot-plate test.

\begin{tabular}{lcccccc}
\hline & & \multicolumn{5}{c}{ Reaction time after first stimulus (s) } \\
\hline Treatment & Dose $(\mathrm{mg} / \mathrm{kg})$ & $0 \mathrm{~min}$ & $30 \mathrm{~min}$ & $60 \mathrm{~min}$ & $90 \mathrm{~min}$ & $120 \mathrm{~min}$ \\
\hline Vehicle & - & $8.2 \pm 0.9$ & $10.2 \pm 0.5$ & $8.5 \pm 0.6$ & $9.8 \pm 0.5$ & $8.7 \pm 0.8$ \\
EE & 100 & $12.3 \pm 0.8$ & $13.8 \pm 2.2$ & $14.7 \pm 1.7$ & $11.7 \pm 0.6$ & $10.3 \pm 1.1$ \\
& 200 & $13.2 \pm 1.4$ & $14.0 \pm 2.0$ & $13.8 \pm 1.4$ & $11.5 \pm 1.0$ & $11.2 \pm 0.7$ \\
& 400 & $12.5 \pm 1.0$ & $17.5 \pm 2.0^{\mathrm{a}}$ & $18.0 \pm 2.4^{\mathrm{a}}$ & $18.2 \pm 1.8^{\mathrm{a}}$ & $14.8 \pm 0.4^{\mathrm{a}}$ \\
Morphine & 3 & $30.0 \pm 0.0^{\mathrm{a}}$ & $30.0 \pm 0.0^{\mathrm{a}}$ & $29.0 \pm 0.7^{\mathrm{a}}$ & $28.7 \pm 0.6^{\mathrm{a}}$ & $30.0 \pm 0.0^{\mathrm{a}}$ \\
Naloxone+morphine & $5+3$ & $11.4 \pm 4.4^{\mathrm{b}}$ & $11.6 \pm 5.8^{\mathrm{b}}$ & $10.5 \pm 4.9^{\mathrm{b}}$ & $9.7 \pm 6.2^{\mathrm{b}}$ & $8.5 \pm 2.9^{\mathrm{b}}$ \\
Naloxone+EE & $5+400$ & $6.7 \pm 0.5^{\mathrm{c}}$ & $10.7 \pm 0.8^{\mathrm{c}}$ & $8.7 \pm 1.4^{\mathrm{c}}$ & $11.3 \pm 1.6^{\mathrm{c}}$ & $9.0 \pm 1.5^{\mathrm{c}}$ \\
\hline
\end{tabular}

$p<0.05$ vs. ${ }^{\mathrm{a}}$ vehicle, ${ }^{\mathrm{b}}$ morphine, and ${ }^{\mathrm{C}} \mathrm{EE}(400 \mathrm{mg} / \mathrm{kg})$ ( $\mathrm{n}=6 /$ group).

\section{MAP in non-anesthetized rats}

In non-anesthetized normotensive rats, the oral administration of $C$. pyramidalis EE (100, 200, and 400 $\mathrm{mg} / \mathrm{kg}$ ) did not show any significant MAP alterations at any of the time points analyzed (data not shown).

\section{Discussion}

This study evaluated the effects of Caesalpinia pyramidalis Tul., Fabaceae, EE using several acute models of nociception and inflammation in rodents. Our data revealed that $C$. pyramidalis EE significantly diminished the nociceptive and inflammatory responses induced by various agents.

In the abdominal constriction assay, acetic acid acts indirectly causing the release of nociceptive endogenous mediators, such as bradykinin, serotonin (5-HT), histamine, sympathomimetic amines, prostaglandins (PG), and pro-inflammatory cytokines (Ribeiro et al., 2000; Ikeda et al., 2001). Acetic acid can also directly activate non-selective cation channels located at primary afferent pathways (Julius \& Basbaum, 2001). This nociceptive effect can be prevented by nonsteroidal anti-inflammatory drugs, opioids, analgesics with central actions, sympatholytic agents, and substances that reduce intestinal motility (Duarte et al., 1988; Reichert et al., 2001). Our results demonstrated that the EE of $C$. pyramidalis was able to significantly diminish the abdominal writhing induced by acetic acid, likely by interfering with the generation or mechanisms of action of the inflammatory mediators.

In addition, the formalin-induced paw licking assay was employed to evaluate the antinociceptive effect of the EE of $C$. pyramidalis. This test allowed the evaluation of two distinct phases: the first (also called neurogenic) and second (also called inflammatory) phases. The former occurs during the first $5 \mathrm{~min}$ after the formalin injection and is characterized by the direct stimulation of nociceptors presents on afferent $\mathrm{C}$ and in part by $\mathrm{A} \delta$ fibers (glutamate and substance $\mathrm{P}$ release). The latter occurs between the $15^{\text {th }}$ and $30^{\text {th }}$ min after formalin injection and is putatively caused by the release of pro-inflammatory mediators such as adenosine, bradykinin, histamine, PG, and 5-HT (Reeve \& Dickenson, 1995). The treatment with the EE was capable of diminishing the nociceptive response in both the neurogenic and inflammatory phases. This result suggests that the EE of C. pyramidalis might possess anti-inflammatory activity. However, the inhibition presented in the first phase suggests a disruption of either the production or the release of some central neurotransmitters.

Another interesting result of the current study was the fact that EE of $C$. pyramidalis produced a significant antinociceptive effect after the mice were exposed to a thermal stimulus. The hot-plate test, which is performed at a constant temperature, produces two kinds of behavioral responses: paw licking and jumping. Both of these are considered to be supraspinally integrated responses (Chapman et al., 1985). The present results lead us to the conclusion that the opioid system is involved because the pre-treatment with naloxone, a non-selective opioid receptor antagonist, reversed the antinociceptive effect caused by EE of $C$. pyramidalis. Although the hot-plate test is commonly used to assess the effect of narcotic analgesics, some sedatives, muscle relaxants, and psychotomimetics have also shown activity in this test (Eddy \& Leimbach, 1953). This could indicate that this EE may have non-specific central actions, but this hypothesis was proven unlikely by the observation that EE did not influence the performance of mice in the rotarod test, indicating that EE actions may not be due to a motor impairment.

To complement the results obtained in the second phase of the formalin-induced licking response, the EE of $C$. pyramidalis was tested on models of inflammation (paw edema and peritonitis) induced by carrageenan.

In this model, carrageenan-induced rat paw edema occurs as a non-immune reaction and is used to evaluate the effects of anti-inflammatory drugs. The edema formed is a multi-mediated phenomenon divided in two phases. The first phase (which last up to $2 \mathrm{~h}$ after carrageenan 
injection) is due to liberation of histamine, 5-HT, and bradykinin in paw tissue, while the second phase ( 3 and $4 \mathrm{~h}$ after carrageenan treatment) is sustained by liberation of PG (Di Rosa, 1972). In this study, EE of C. pyramidalis effectively reduced the edematogenic responses evoked by carrageenan between 2 and $4 \mathrm{~h}$ after the injection. These effects may be related to a reduction in the release or actions of histamine, 5-HT, bradykinin, or PG on local tissue.

The EE of $C$. pyramidalis also significantly decreased the elevated paw MPO activity, which is currently used as an indicator of neutrophil presence in inflamed tissues, suggesting that the inhibition of neutrophil infiltration may be another characteristic of the anti-inflammatory actions of this EE. This was further investigated using carrageenan as a stimulus to produce an acute inflammatory response in the peritoneal cavity of mice, which is a widely accepted model for induction of a massive influx of leukocytes (mainly neutrophils) to this cavity. The EE of C. pyramidalis inhibited both the total migration and the PMN migration induced by carrageenan at the same dose that inhibited the paw edema formation. The mechanism of action of carrageenan on peritonitis involves synergistic action between $\mathrm{PG}$, leukotriene $\mathrm{B}_{4}$, and other chemotactic agents, which promote an increase of the vasodilatation, exudation, and recruitment of leukocytes (Foster et al., 1986). As these anti-edematogenic and anti-chemotatic actions of EE could be strongly influenced by the possible vasoconstrictor effects of this extract, we conducted experiments to evaluate this possibility by measuring the mean arterial pressure of non-anesthetized rats after the administration of EE. We found that the doses of EE of $C$. pyramidalis used did not alter the mean arterial pressure, indicating that the anti-inflammatory activity of EE is not linked to alterations in the blood supply to the local of injury and might instead be related to the interference of the generation or mechanisms of action of inflammatory mediators. Furthermore, this hypothesis is supported by the antinociceptive effects of this extract, such as those observed in the second phase of the formalin-induced nociceptive test and the acetic acid-induced writhing test.

In summary, the data reported in this work confirmed the anti-inflammatory indications of $C$. pyramidalis, which have been observed in traditional medicinal practices. Additionally, this study suggests, for the first time, that $C$. pyramidalis has relevant antinociceptive properties in acute pain-like behavioral animal models. The mechanisms by which the EE of $C$. pyramidalis exerts its actions require further studies.

\section{Acknowledgements}

This study was supported by Conselho Nacional de Desenvolvimento Científico e Tecnológico. CA Santos and AMPR Passos received grants from CNPq.

\section{References}

Albuquerque UP, Medeiros PM, Almeida ALS, Monteiro JM, Lins Neto EMF, Melo JG, Santos JP 2007. Medicinal plants of the caatinga (semi-arid) vegetation of $\mathrm{NE}$ Brazil: A quantitative approach. J Ethnopharmacol 114: 325-354.

Bradley PP, Priebat M, Christensen M, Rothstein G 1982. Measurement of cutaneous inflammation: estimation of neutrophil content with an enzyme marker. J Invest Dermatol 78: 206-209.

Carvalho JCT, Teixeira JRM, Souza PJC, Bastos JK, Santos Filho D, Sarti SJ 1996. Preliminary studies of analgesic and anti-inflammatory properties of Caesalpinia ferrea crude extract. $J$ Ethnopharmacol 53: 175-178.

Chapman CR, Casey KL, Dubner R, Foley KM, Graceley RH, Reading AE 1985. Pain measurement: an overview. Pain 22: 1-31.

Deharo E, Bourdy G, Quenedo C, Muñoz V, Sauvin MA 2001. A search for natural bioactive compounds in Bolivia through a multidisciplinary approach. Part V. Evaluation of the antimalarial activity of plants used by the Tacana Indians. J Ethnopharmacol 77: 91-98.

Di Rosa M 1972. Biological properties of carrageenan. J Pharm Pharmacol 24: 89-102.

Duarte ID, Nakamura M, Ferreira SH 1988. Participation of the sympathetic system in acetic acid-induced writhing in mice. Braz J Med Biol Res 21: 341-343.

Duham NW, Miya TS 1957. A note on a simple apparatus for detecting neurological deficit in rats and mice. $J \mathrm{Am}$ Pharm Assoc 46: 208-209.

Eddy NB, Leimbach D 1953. Synthetic analgesics. II. Dithienylbutenyland dithienylbutylamines. JPharmacol Exp Ther 107: 385-393.

Foster SJ, McCormick ME, Howarth A, Aked D 1986. Leukocyte recruitment in the subcutaneous sponge implant model of acute inflammation in the rat is not mediated by leukotriene B4. Biochem Pharmacol 35: 1709-1717.

Hikino H, Tagushi T, Fujimura H, Hiramatsu Y 1977. Antiinflammatory principles of Caesalpinia sappan wood and of Haematoxylon campechianum wood. Planta Med 31: 214-220.

Hunskaar S, Hole K 1987. The formalin test in mice: dissociation between inflammatory and non-inflammatory pain. Pain 30: 103-114.

Ikeda Y, Ueno A, Naraba H, Oh-Ishi S 2001. Involvement of vanilloid receptor VR1 and prostanoids in the acetic acid-induced writhing response of mice. Life Sci 69 : 2911-2919.

Julius D, Basbaum AI 2001. Molecular mechanism of nociception. Nature 413: 203-210.

Koster R, Anderson N, Debber EJ 1959. Acetic acid for 
analgesic screening. Fed Proc 18: 418-420.

Kuria KAM, De Coster S, Muriuki G, Masengo W, Kibwage I, Hoogmartens J, Laekeman GM 2001. Antimalarial activity of Ajuga remota Benth (Labiatae) and Caesalpinia volkensii Harms (Caesalpiniaceae): confirmation of ethnopharmacological use. $J$ Ethnopharmacol 74: 141-148.

Matos FJA 1997. Introdução a Fitoquímica Experimental. Fortaleza, Brazil: Edições UFC.

Mendes SS, Bomfim RR, Jesus HCR, Alves PB, Blank AF, Estevam CS, Antoniolli AR, Thomazzi SM 2010. Evaluation of the analgesic and anti-inflammatory effects of the essential oil of Lippia gracilis leaves. $J$ Ethnopharmacol 129: 391-397.

Menezes AC, Moreira IJA, Carvalho AA, Antoniolli AR, Santos MRV 2007. Cardiovascular effects of the aqueous extract from Caesalpinia ferrea: Involvement of ATP-sensitive potassium channels. Vasc Pharmacol 47: 41-47.

Phillipson JD, Anderson LA 1989. Ethnopharmacology and Western Medicine. J Ethnopharmacol 25: 61-72.

Reeve AJ, Dickenson AH 1995. The roles of spinal adenosine receptors in the control of acute and more persistent nociceptive response of dorsal horn neurons in the anaesthetized rat. Brit J Pharmacol 116: 2221-2228.

Reichert JA, Daughters RS, Rivard R, Simone DA 2001. Peripheral and preemptive opioid antinociception in a mouse visceral pain model. Pain 89: 221-227.
Ribeiro RA, Vale ML, Thomazzi SM, Paschoalato AB, Poole S, Ferreira SH, Cunha FQ 2000. Involvement of resident macrophages and mast cells in the writhing nociceptive response induced by zymosan and acetic acid in mice. Eur J Pharmacol 387: 111-118.

Saeed MA, Sabir A 2001. Antibacterial activity of Caesalpinia bonducella. Fitoterapia 72: 807-809.

Sharma SR, Dwivedi SK, Swarup D 1997. Hypoglycaemic, antihyperglycaemic and hypolipidemic activities of Caesalpinia bonducella seeds in rats. J Ethnopharmacol 58: 39-44.

Winter CA, Risley EA, Nuss GW 1962. Carrageenin-induced edema in hind paw of the rat as an assay for antiinflammatory drugs. Proc Soc Exp Biol Med 111: 544547.

Woolfe G, Macdonald AD 1944. The evaluation of the analgesic action of penthidine hydrochloride (Demerol). $J$ Pharmacol Exp Ther 80: 300.

\section{*Correspondence}

Sara Maria Thomazzi

Departamento de Fisiologia, Universidade Federal de Sergipe Av Marechal Rodon s/n, 49100-000 São Cristóvão-SE, Brazil, sarathomazzi@ufs.br

Tel: +55 7921056640

Fax: +55 7921056474 